UDC 622.276.1/.4

DOI: 10.17122/ngdelo-2018-5-44-54

\title{
ANALYSIS OF THE APPLICABILITY OF LOW SALINITY WATERFLOODING IN THE GULF OF GUINEA
}

\author{
АНАЛИЗ ПРИМЕНИМОСТИ ЗАВОДНЕНИЯ \\ С ПОНИЖЕННОЙ СОЛЕНОСТЬЮ В ЗАЛИВЕ ГВИНЕИ
}

\section{R. Yeboah \\ Раиса Йебоах}

\author{
Gubkin Russian State University \\ of Oil and Gas (National \\ Research University), \\ Moscow, Russian Federation \\ Российский государственный \\ университет нефти и газа \\ (Национальный \\ исследовательский университет) \\ имени И.М. Губкина, \\ г. Москва, Российская Федерация
}

It is estimated by the Energy Information Administration (EIA) that between 2003 and 2030, the world will increase its energy use by $71 \%$, requiring about $\$ 6$ trillion investment in oil and gas exploitation in order to meet present and future demands of energy. Africa contributes around 10 million barrels per day (bpd) and about 185,02 billion cubic meters (bcm) of natural gas to the global production. With $70 \%$ of this value being in West Africa, focus has defintly moved to the petroleum producing Gulf of Guinea. This region holdsnumerous proven reservoirs that are made up primarily of sandstone characterized with the presence of shale. Most of the fields under exploitation in this region use water flooding to maintain their reservoir pressure. Low salinity has been successfully applied on sandstonefields such as the BP Claire Ridge, Mad Dog and Thunderhorse, and start oil's Peregrino field Thus, the application of low salinity water flooding (LoSal) seems to be a viable option for improvement the productivity of the region. This has shown to bring about an increase of from $5-40 \%$ based on original oil in place.

По оценкам Администрации энергетической информации (EIA), в период с 2003 по 2030 год потребление энергии в мире увеличится на $71 \%$, что потребует около 6 трлн долларов инвестиций в нефтегазовую добычу, чтобы обеспечить нынешние и будущие потребности в энергии. Африка добывает около 10 млн баррелей/сут и около 185,02 млрд м ${ }^{3}$ природного газа суммарного к мировому производству. Поскольку 70 \% этой доли находится в Западной Африке, основное внимание уделяется добыче нефти в Гвинейском заливе. В этом регионе есть много доказанных месторождений, которые состоят в основном из песчаника, характеризующегося наличием сланца. Большинство месторождений в этом регионе эксплуатируются нагнетанием водой для поддержания пластового давления. Применение воды с пониженной соленостью было применено на месторождениях, таких как BP Claire Ridge, Mad Dog и Thunder Horse, и Peregrino от Startoil. Таким образом, применение воды с пониженной соленостью (LoSal), по-видимому, является актуальным вариантом для повышения продуктивности. Это показало увеличение на 5-40\% от первоначальных запасов нефти.

\section{Key words}

\author{
low salinity water flooding, \\ Gulf of Guinea, desalination, \\ reverse osmosis, \\ sandstone reservoir
}

\section{Ключевые слова}

применение воды пониженной солености, Гвинейский залив, опреснение, обратный осмос, песчаный резервуар 
As seen from figure 1 and 2 the Gulf of Guinea province includes the Ivory coast, Saltpond, Tano, Central, Keta and Benin Basins and the Dahomey Embayment in the northwestern part of the Gulf of Guinea.

At least five total petroleum systems (TPS) exist in the Gulf of Guinea Province (7183): (1) the Lower Paleozoic TPS, consisting of Devonian source rocks and Devonian to Lower Cretaceous reservoir rocks; (2) the Lower Cretaceous TPS, consisting of Lower Cretaceous lacustrine source rocks and Cretaceous reservoir rocks; (3) the middle Albian Terrestrial TPS, consisting of gasprone source rocks and Albian reservoir rocks; (4) the upper Albian TPS, consisting of marine transgressive oil-prone source rocks and Albian reservoir rocks; and (5) the CenomanianTuronian TPS, consisting of open marine oil- prone source rocks and Albian to Upper Cretaceous reservoir rocks [2].

The oldest proven reservoir rocks in the Gulf of Guinea Province are Devonian to Carboniferous sandstone beds in the Saltpond field of Ghana. The sands that make up the Devonian reservoirs are deposited in shallow to restricted marine environments. However, the sands forming the Carboniferous reservoirs are deposited in fluvial environments [2]. Similar reservoir rocks may exist westward across the province in the Ivory Coast Basin where there will predominantly be sandstone and shales. Clastic Albian rocks are found in several producing fields in Ivory Coast Basin, these are also known as Tano and Keta Basins [3]. The offshore part of the Benin Basin is also made up of Albian sandstone. From here one can see that most of the reservoir formations are mostly a combination of sandstones and shale.

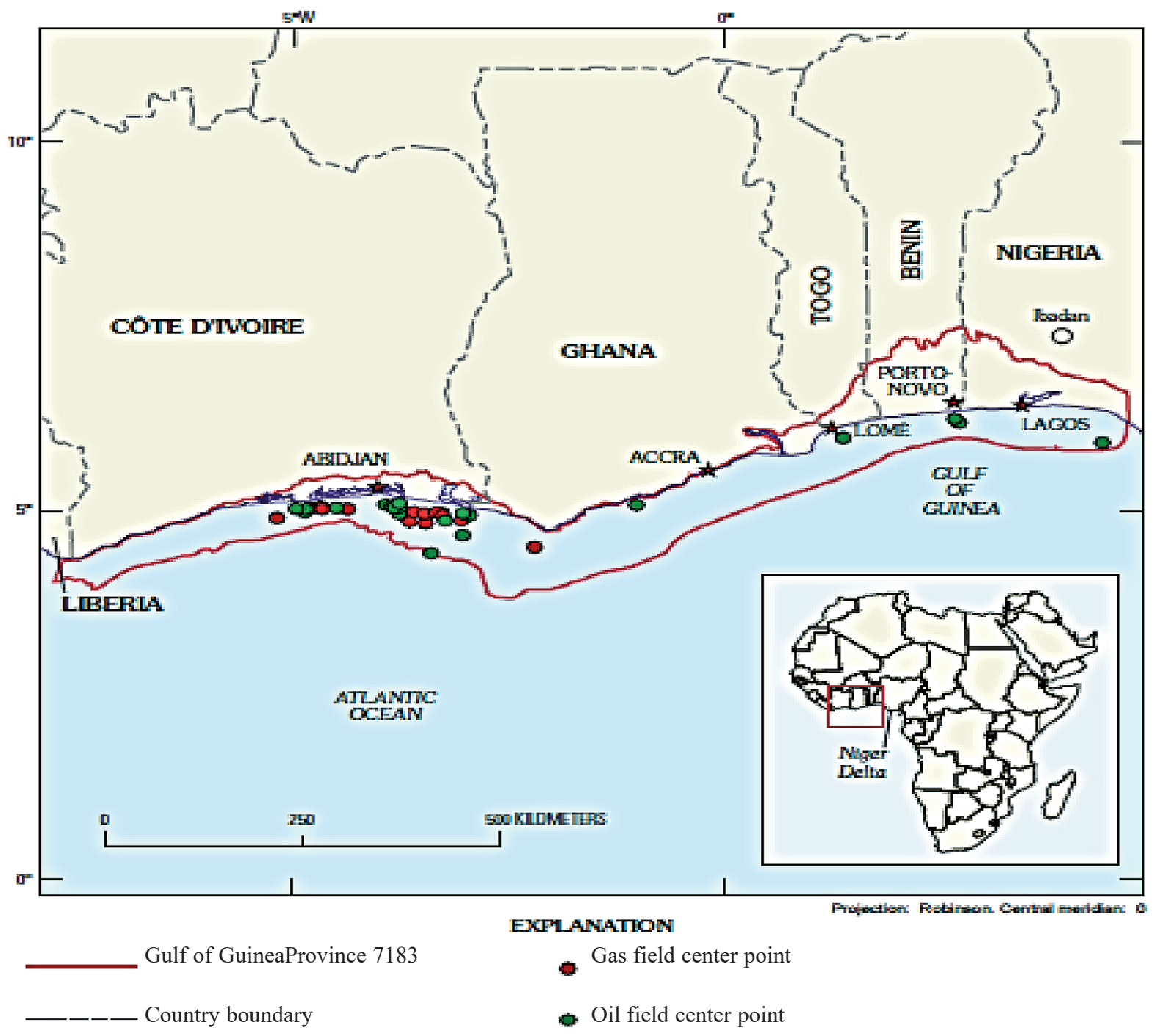

Figure 1. Gulf of Guinea Province in West-Central Africa [1] 


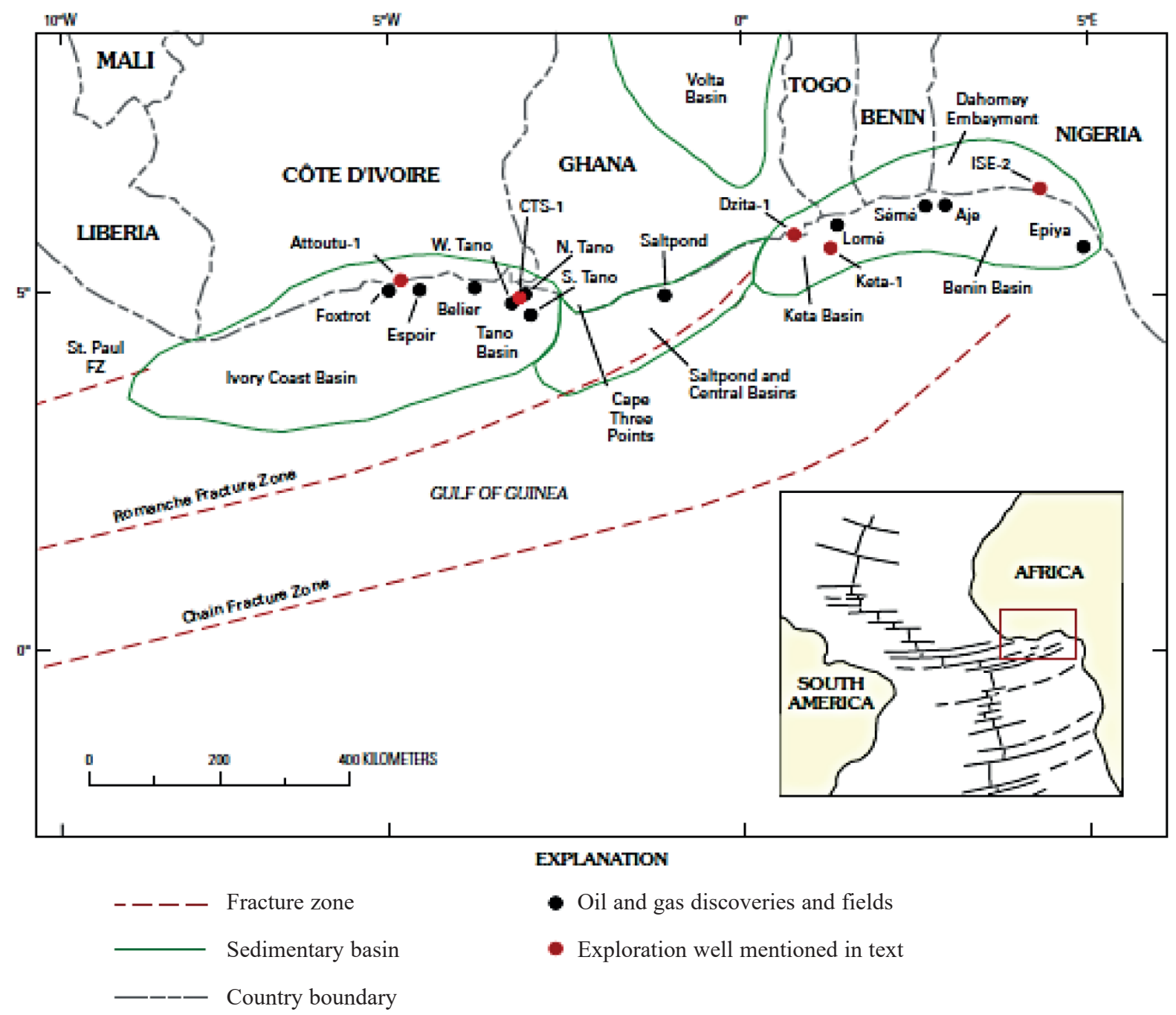

Figure 2. Major features of the Gulf of Guinea Province, West Africa: Central, Ivory Coast, Keta, Saltpond, Tano and Volta basins and major fractures [2]

From table 1 it is clear the Gulf of Guinea still holds much promise for the future. It is estimated tohave mean undiscovered resources of 1,004 million barrels of conventional undiscovered oil, 10,071 billion cubic feet of gas, and 282 million barrels of natural gas liquids in undiscov- ered fields [2]. The amounts of proposed undiscovered oil and gas makes this place a prime location for further development and the application of new technologies to improve on production such as LoSal technology which as an affinity to sandstone and shale reservoirs.

Table 1. Summary of estimated undiscovered volumes of conventional oil, gas and natural gas ilquids from undiscovered petroleum fields in the Cretaceous Composite Total Petroleum System of the Gulf of Guine Province

\begin{tabular}{|c|c|c|c|c|c|c|c|c|c|c|c|c|c|c|}
\hline \multirow{3}{*}{$\begin{array}{l}\text { Field } \\
\text { Type }\end{array}$} & \multirow{3}{*}{ MFS } & \multirow{3}{*}{$\begin{array}{l}\text { Prob. } \\
(0-1)\end{array}$} & \multicolumn{12}{|c|}{ Undiscovered Resources } \\
\hline & & & \multicolumn{4}{|c|}{ oil (MMBO) } & \multicolumn{4}{|c|}{ Gas (BCFG) } & \multicolumn{4}{|c|}{ NGL(MMBNGL) } \\
\hline & & & F95 & $\mathrm{F} 50$ & $\mathrm{F5}$ & Mean & F95 & $\mathrm{F} 50$ & F5 & Mean & F95 & $\mathrm{F} 50$ & $\mathrm{~F} 5$ & Mean \\
\hline & \multicolumn{14}{|c|}{$\begin{array}{l}\text { Cretaceous Composite Total Petroleum System } \\
\text { Coastal Plain and Offshore Assessment Unit Offsho }\end{array}$} \\
\hline Oil Fields & \multirow{2}{*}{\multicolumn{2}{|c|}{\begin{tabular}{r|r}
2 & \\
12 & 1. \\
\end{tabular}}} & \multirow[t]{2}{*}{225} & \multirow[t]{2}{*}{901} & \multirow[t]{2}{*}{2,117} & \multirow[t]{2}{*}{1,004} & 918 & 3,846 & 9,845 & 4,420 & 29 & 124 & 339 & 146 \\
\hline Gas Fiedds & & & & & & & 1,256 & 5,064 & 12,000 & 5,650 & 28 & 118 & 303 & 136 \\
\hline Tota & & 1.00 & 225 & 901 & 2,117 & 1,004 & 2,174 & 8,910 & 21,846 & 10,071 & 57 & 242 & 642 & 282 \\
\hline
\end{tabular}

MMBO, million barrels of oil. BCFG, billion cubic feet of gas. MMBNGL, million barrels of natural gas liquids. MFS, minimum field size assessed (MMBO or BCFG). Prob., probability (including both geologic and accessibility probabilities) of at least one field equal to or greater than the MFS. Results shown are fully risked estimates. For gas fields, all liquids are under the NGL (natural gas liquids) category. F95 represents a 95 percent chance of at least the amount tabulated. Other fractiles are defined similarly. Fractiles are additive under the assumption of perfect positive correlation. Shading indicates not applicable. 
Low salinity technology is a highly promising EOR method where desalinated seawater is injected into a petroleum reservoir. Benefits of reduced salinity waterflood over high salinity waterflood range from $5-40 \%$ based on original oil in place. This can be applied both as a secondary and a tertiary EOR method. Low salinity as a secondary waterflood application implies that reduced salinity water injection is carried out from day one. Low salinity as a tertiary waterflood application however implies that reduced salinity injection follows higher salinity water injection.

The first core plug experiments were conducted by Bernard containing hydratable clays [4] in which he concluded that more oil was recovered from fresh water flooding as compared to brine flooding. Interestingly enough after many years of research, scholars have still not been able o agree on the exact mechanism of oil recovery for this technology. There are several schools of thought highlighting several key mechanisms [5]:

- Wettability alteration;

- Rock dissolution;

- Electric double layer effect (EDL);

- Interfacial tension (IFT) reduction.

These have all been proven by several research publications to effect the process to some degree. Which mechanism is the primary determining factor has to still be agreed upon. However it is also possible that it may be a combination of several factors.

Most research work and field applications have been mostly applied in sandstone reservoirs due to the extra challenges that are encountered when the technology is adapted for carbonate reservoirs. They in general have a lower water wetness, there exists a higher level of heterogeneity and complexity of reservoir structure, the understanding of the ionic interaction in carbonate reservoirs with LoSal water is more complicated due to the oil wet nature of carbonates and the general deficiency in research in this area increases the risk factor if applied.

Reservoir lithology is one of the primary screening criteria in the selection of any enhanced oil recovery method (EOR). From figure 3, one can see that most enhanced oil recovery (EOR) methods are applied in sandstone reservoirs, with a $50 \%$ gap between itself and carbonate reservoirs. Thus LoSal technology has great prospects for the future [6].

Certain basic conditions must exist for the technology to be feasible in sandstones:

- Porous medium: Sandstones containing clay minerals $(>10 \%$, significant kaolinite content uniformly distributed [7]);

- Oil: Must contain polar components (i.e. acids and/or bases);

- Mixed or intermediate wettability;

- Formation water: Must be present, and must contain divalent cations, i.e. $\mathrm{Ca}^{2+}, \mathrm{Mg}^{2+}$;

- Low salinity injection fluid: The salinity is usually between 1000-2000 ppm, but effects have been observed up to $5000 \mathrm{ppm}$. It appeared to be sensitive to ionic composition $\left(\mathrm{Ca}^{2+} \mathrm{vs} \mathrm{Na}^{+}\right)$.

LoSal technology has many benefits including a high improved oil recovery (IOR), cost effectiveness, low $\mathrm{CO}_{2}$ footprint, minimal environmental effectsand operational simplicity and can

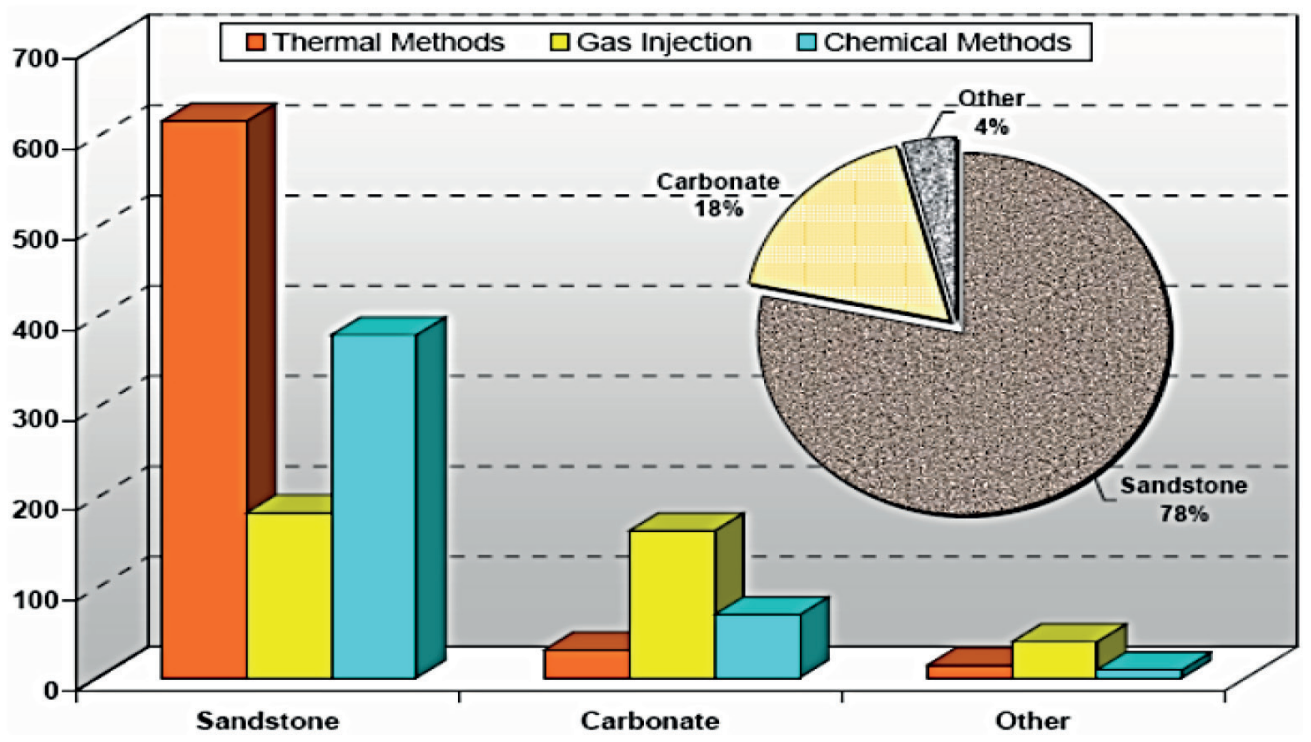

Figure 3. EOR methods by lithology (based on a total of 1,507 projects) 
be combined with other recovery methods such as polymers, alkaline or silicate and carbonated water. Effective and efficient desalination is critical for the success of Low salinity applications. Thus, the desalination technology must be selected in such a way to make the process economically viable.

Desalination can be divided into 4 major groups:

- Thermally activated systems: multi-stage flash distillation (MSF), multiple-effect distillation (MED), vapor compression distillation (MVC), humidification - dehumidification desalination (HDH), solar distillation(SD) and freezing (Frz).

- Pressure-activated systems: reverse osmosis (RO), forward osmosis (FO), electro-dyalysis (ED) and nanofiltration (NF).

- Chemically-activated desalination methods: ion-exchange desalination (I.Ex), liquid-liquid extraction (LLE) and gas hydrate (G.Hyd)

- Adsorption technology (Ads).

In general seawater has an average of 35,000 ppm TDS concentration [8]. Thus any de- salination technology should be able to desalinate a solution with a minimum of $35,000 \mathrm{ppm}$ TDS. These technologies are all in different stages of development to truly suit the challenging and demanding environments that exist offshore. Table 2 shows that only certain methods aretheoretically applicable offshore for the desalination of seawater due to their limits in salinity, both in feed and produced water [9]. These methods are: MSF, MED, MVC, RO, FO and Abs. the general mechanism of the methods have been described below.

\section{Reverse osmosis (RO)}

This method is based on the common concept of osmosis. Osmosis is defined as the tendency of a fluid, usually water to flow through a semipermeable membrane intoa solution where the solvent solution is higher. This will happen as long as the osmotic pressure difference $\Delta \prod$ is greater than the pressure difference $\Delta \mathrm{p}$, which in turn depends on the difference in concentrations of the solutions at both sides of the semi-permeable membrane (figure 4).

Table 2. Desalination systems capabilities regarding salinity of feed and produced water measured in ppm

\begin{tabular}{|l|l|c|c|}
\hline \multicolumn{2}{|l|}{ Technology } & Feed water salinity, $* 10^{3}(\mathrm{ppm})$ & Produced water salinity $(\mathrm{ppm})$ \\
\hline \multirow{5}{*}{ Thermal } & MSF & 70 & 10 \\
\cline { 2 - 4 } & MED & 45 & 10 \\
\cline { 2 - 4 } & MVC & 42 & 10 \\
\cline { 2 - 4 } & HDH & 35 & 400 \\
\cline { 2 - 4 } & SD & 55 & 80 \\
\cline { 2 - 4 } & FRZ & 37 & 100 \\
\hline \multirow{5}{*}{ Membrane } & RO & 45 & 10 \\
\cline { 2 - 4 } & FO & 45 & 6 \\
\cline { 2 - 4 } & ED & 6 & 250 \\
\cline { 2 - 4 } & NF & 1 & 90 \\
\hline \multirow{5}{*}{ Chemical } & I.Ex & 1,5 & 13 \\
\cline { 2 - 4 } & G.Hyd & 35 & 100 \\
\cline { 2 - 4 } & LLE & 45 & 200 \\
\hline
\end{tabular}

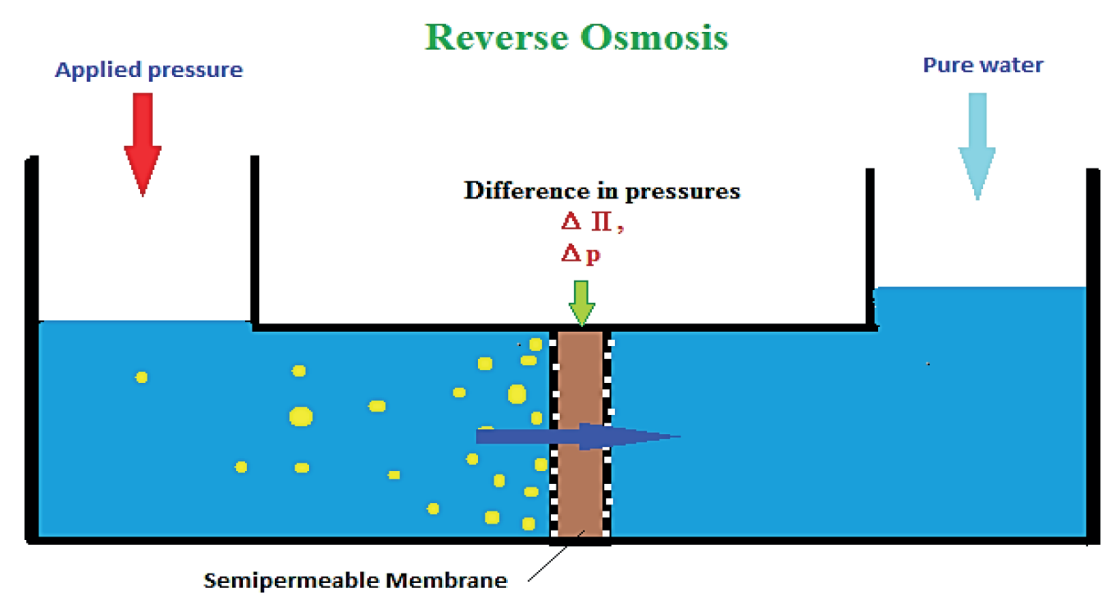

Figure 4. Mechanism of reverse osmosis 
On the other hand reverse osmosis takesplace when $\Delta \mathrm{p}$ is larger than $\Delta \prod$. This is an artificial process that allows the flow of most often water from a more concentrated solution to a less concentrated solution [10].

There are several types of membranes that can be used for the RO process. These membranes are often very thin due to flux.

Cellulose-acetate (CA) membranes were the first membranes used commercially for RO and are still used in the industry.

The Asymmetric membrane [10] consist of two layers; one active non porous layer that prevents the transport of mass through the membrane and one porous supporting layer that prevents ripping.

Composite membranes, these are gaining much popularity in the industry. They are composed of one active layer made of polyamide and one porous supporting layer which as the option of having a made from different materials.

Composite membranes have certain advantages over the traditional CA membranes. They are more physically and chemically stable, they resist bacterial degradation and do not hydrolyze. However they have a tendency to foul as compared to CA membranes that are in general less hydrophilic [10].

Most membranes of late have taken on a spiral wound module [10]. It is made up of multiple sheet membranes that are glued together with a permeate spacer in between. The perforated central tube resultantly has membrane pockets being formed. Feed channel spacers are placed between each membrane pocket to create alternating feed and permeate channels. The feed is then forced through the layers that are rolled around the tube. The spiral is cheap, easy to manufacture, has a well-balanced permeability and has a high packing density. However it is also difficult to clean and fouls easily (figure 5).

\section{Forward osmosis}

This is also known as «direct osmosis», fresh water is generated from saline water as it passes through a semipermeable membrane with a high osmotic pressure concentrated draw solution [11]. As soon from figure 6, osmotic pressure is used to separate water across the membrane rather than the conventional hydraulic pressure gradient. Fresh water dilutes the draw solution after passing through the semipermeable membrane. The draw solution is then concentrated in a recovery system to produce water. Membranes must be developed to have high water flux, and low fouling [12].

\section{Multistage flash distillation (MSF)}

This is another common method for desalination of sea water, this happens under low temperature in a vacuum environment. This can produce about the $20 \%$ water product. The vapor condenses to form fresh water. Water boils at a lower temperature in a vacuum environment thus consuming less energy.

The cold sea water passes through the condensing coils in the vacuum flash chambers. These preheat the cold water and condense the

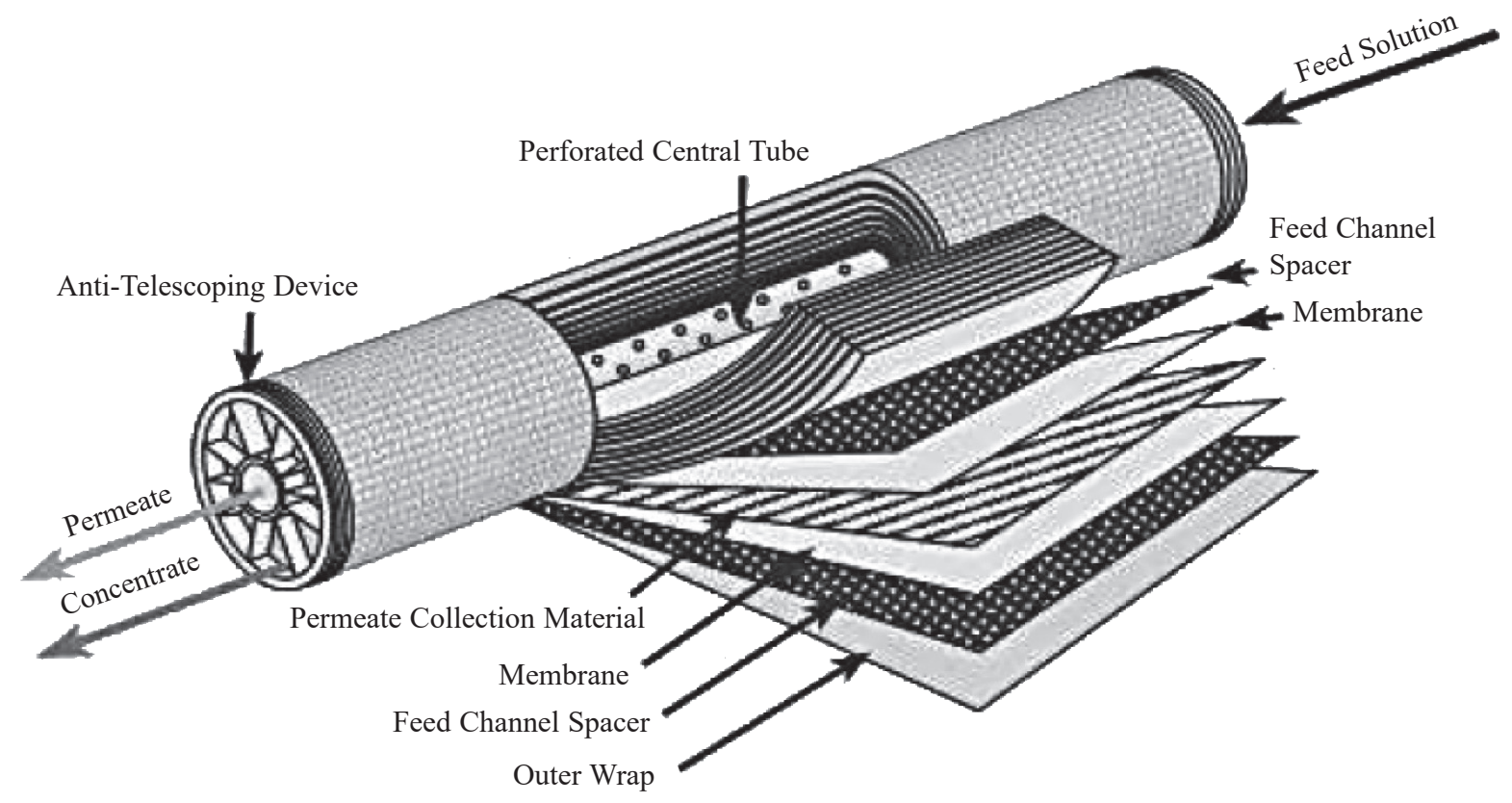

Figure 5. A spiral wound module 


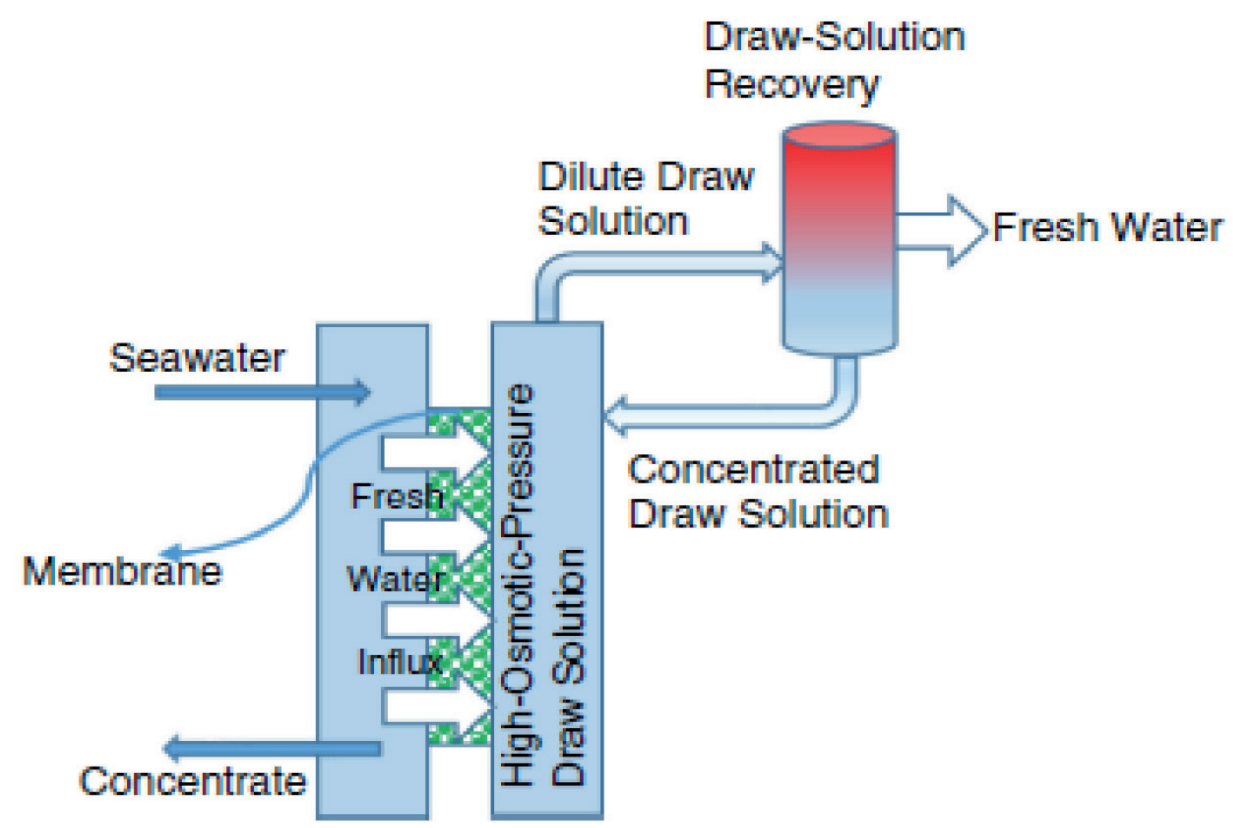

Figure 6. Schematic of forward osmosis process

flashed steam in the chambers to produce fresh water.The sea water heats to around $90-110{ }^{\circ} \mathrm{C}$ whilst passing through the brine heater [13]. The hot brine enters the flash chamber, the entering water temperature is higher than the boiling temperature at the vacuum pressure. Thus, some of the water flashesto steam. The steam rises and condenses to pure water. Salt and other impurities remain at the bottom. This balance brine goes to the next chamber where the process then repeats. This increases the quantity of water. The balance brine returns to the sea (figure 7).

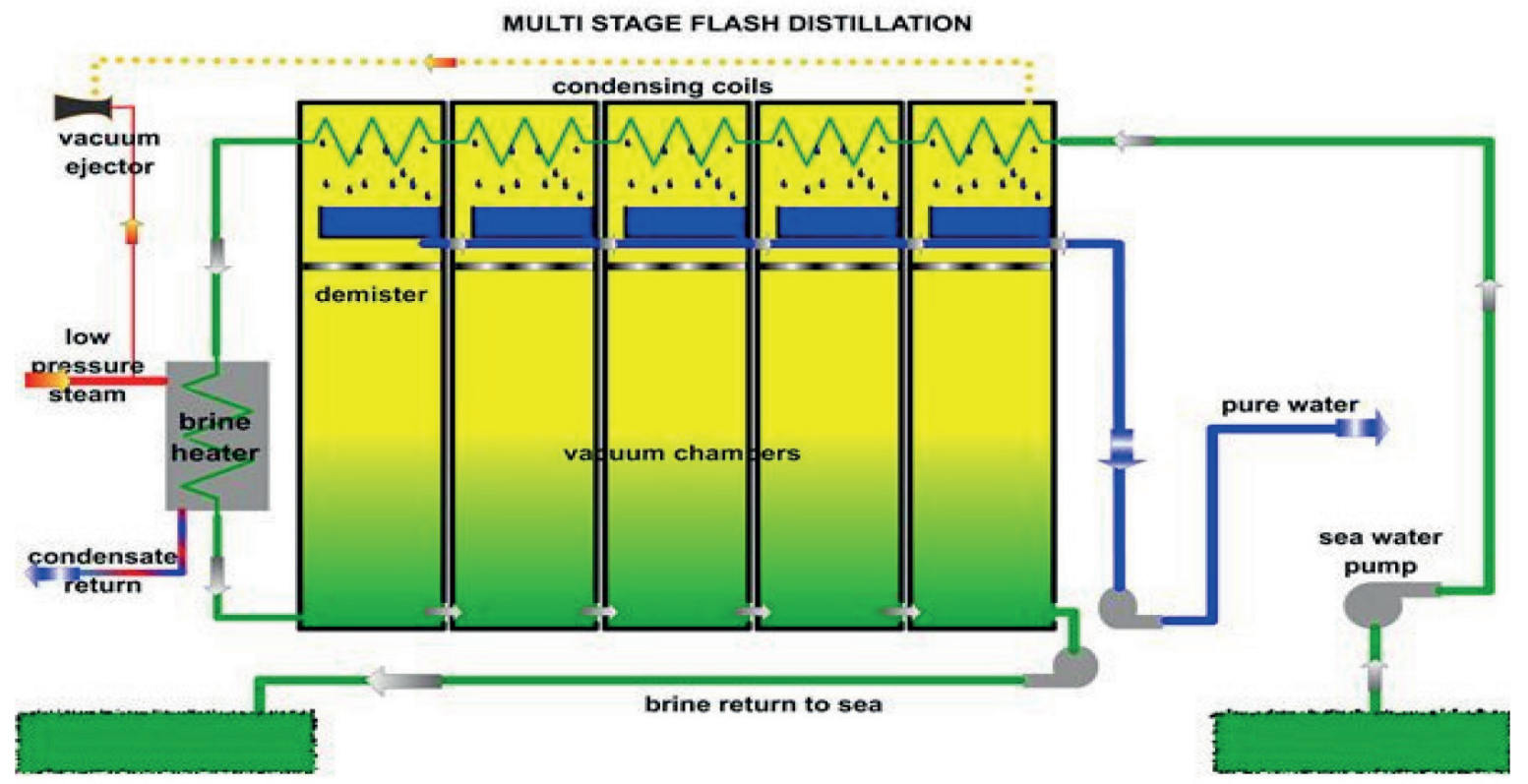

Figure 7. A multistage flash distillation system

\section{Multiple effect distillation (MED)}

This technology relies on the reuse of steam produced to extract clean water from seawater. The desalination unit consists of coherent cells known as effects, these work under decreasing temperature and pressure. Each cell has bundle of tubes containing heated stem. These tubes are sprayed with seawater and the steam condenses into distillate (fresh water) inside the tubes as a result (figure 8 ). The seawater also partially evaporates and the resultant brine flows to the bottom of the cell. The resultant vapor is reused as a heating media for the next effect. This process is repeated in the next cell at less temperature and 


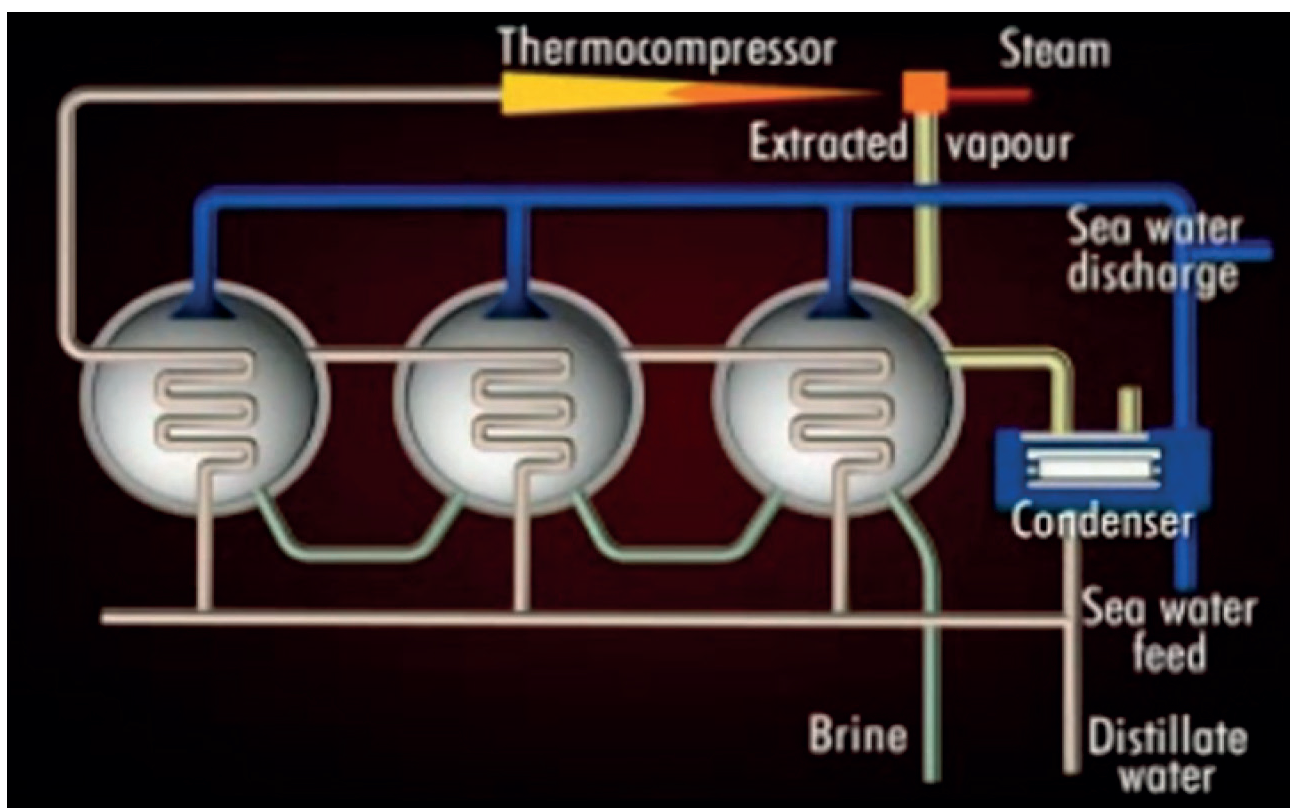

Figure 8. Multiple effect distillation (MED) desalination system

pressure. All the distillate and brine are collected from cell to cell [14].

Mechanical vapor compression (MVC)

The heat used to evaporate part of the feed, which flows from one side of a heat transfer surface, is supplied through the simultaneous condensation of distillate found on the other side of the surface (figure 9). The «heat pump work» work and the fraction required for liquid pumping are the only energy actually spent by the setup.
The heat produced by the compressor work is rejected in the outgoing product and brine systems that are discarded at a higher temperature as compared to the seawater feed. The incoming seawater feed is preheated by means of two plate heat exchangers in order to maintain the high operating temperature. This system does not require cooling water and is considered the most thermodynamically efficient process of a single purpose thermal desalination plant [15].

MVC process schematic

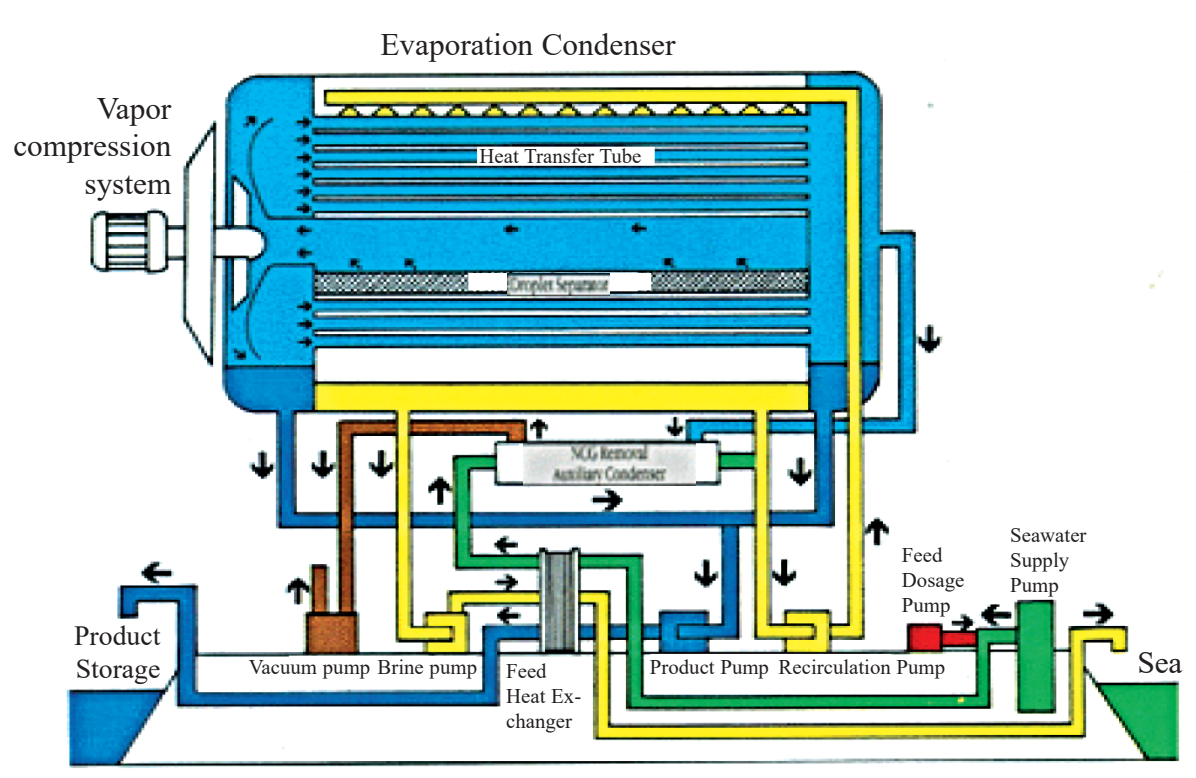

- Feed

- Brine

a Water vapor

- Product

- NCG

- Scale inhibitor

Figure 9. Mechanical vapor compression (MVC) schematic process

Adsorption technology (Ads) / Adsorption desalination system (ADS)

This is a two bed absorption system. The process first starts in bed 1 where desorption starts and then moves to bed 2 for absorption. After half cy- cle, desorption is proceeded in bed 2 and the absorption process is proceeded in bed 1 (figure 10).

The operation can be divided into evaporation - absorption process and desorption - condensation processes. The salt water is evaporated 


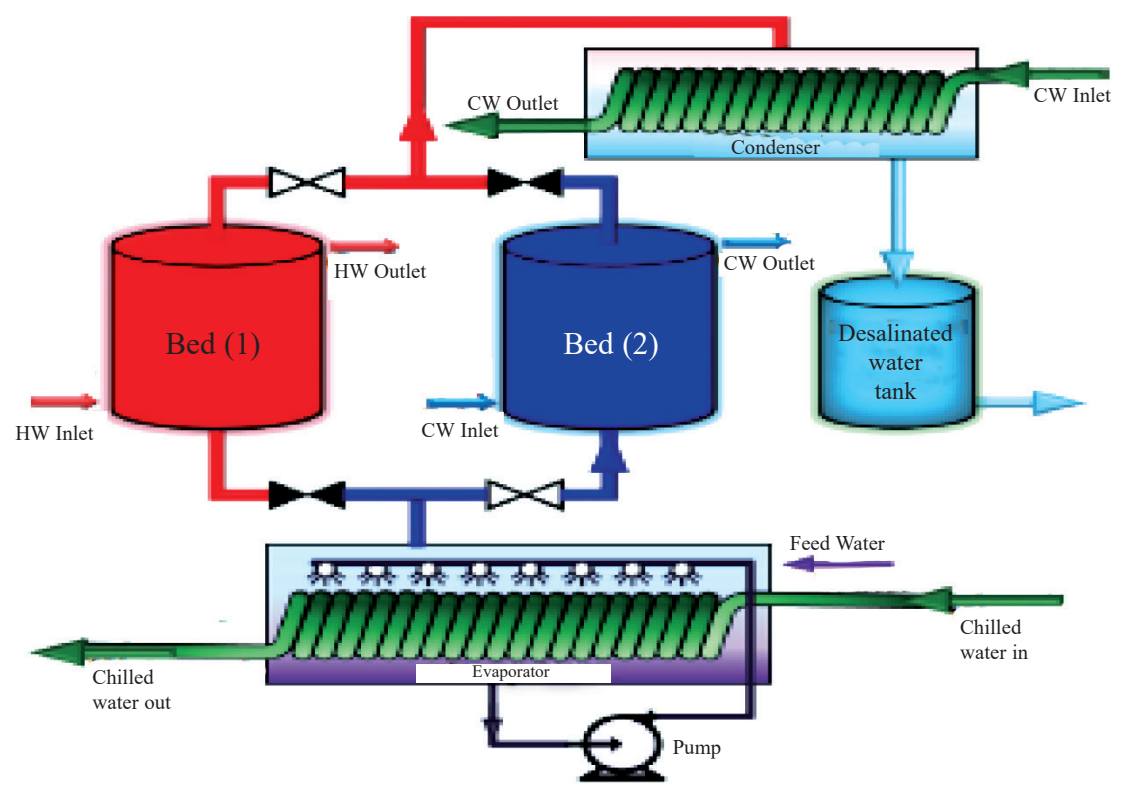

Figure 10. Two beds absorption desalination system

by suction effect from the absorbent which takes place at the evaporator in low conditions of pressure and temperature. Heat is released by cooling water. The regeneration of the absorbent is facilitated by low grade heat which is supplied to the bed in desorption mode. The water vapor migrates to the condenser and then the desalination water is collected in the collection tank [3]. ADS is has a generally low annualized unit production cost, no moving parts making it low maintenance costs, environmentally friendly and low fouling rate.

From [9] further analysis one can see from table 2 that these technologies also vary in their values for energy consumption and water production. These values play a critical role in the selection of a method for desalination since their vales reflect on the economics of the project.
Analyzing tables 2 and 3 together one can make a conclusion that $\mathrm{RO}$ and $\mathrm{FO}$ are the best options when it comes to the above parameters. FO in comparison to RO displays a much better degree of energy consumption it consumes $39 \%$ less energy. Taking water production running cost into consideration one can see that the values are quite similar with only a difference of $0.05 \$ / \mathrm{m}^{3}$ [9].

However, RO is a tried and tested technology that has been applied successfully in fields such as ENDICOTT field during the application of low salinity technology. Here RO was used for the production of $50 \mathrm{MBD}$ of low salinity water from $150 \mathrm{MBD}$ seawater [16]. RO was also applied successfully by British Petroleum in 2004 on the Claire Ridge Project [17] to mention a few.

Table 3. Amount of energy required for different desalination technologies and the corresponding potable water production cost

\begin{tabular}{|c|c|c|c|c|c|}
\hline \multirow[b]{2}{*}{ Technology } & & \multicolumn{3}{|c|}{ Energy consumption } & \multirow{2}{*}{$\begin{array}{l}\text { Water production } \\
\text { running cost }\left(\$ / \mathrm{m}^{3}\right)\end{array}$} \\
\hline & & $\begin{array}{c}\text { Electrical energy } \\
\left(\mathrm{kWh} / \mathrm{m}^{3}\right)\end{array}$ & $\begin{array}{c}\text { Thermal energy } \\
\left(\mathrm{kWh} / \mathrm{m}^{3}\right)\end{array}$ & $\begin{array}{c}\text { Total energy consumption } \\
\left(\mathrm{kWh} / \mathrm{m}^{3}\right)\end{array}$ & \\
\hline \multirow{6}{*}{ Thermal } & MSF & 5,2 & 19,4 & 24,6 & 0,96 \\
\hline & MED & 3,8 & 16,4 & 20,2 & 0,86 \\
\hline & MVC & 11,1 & 0 & 11,1 & 3,93 \\
\hline & $\mathrm{HDH}$ & 3 & 120 & 123 & 0,92 \\
\hline & SD & 0 & 0 & 0 & 3,9 \\
\hline & FRZ & 11,9 & 0 & 11,9 & 0,34 \\
\hline \multirow{4}{*}{ Membrane } & RO & 8,2 & 0 & 8,2 & 0,75 \\
\hline & FO & 5 & 0 & 5 & 0,8 \\
\hline & ED & 5,5 & 0 & 5,5 & 0,83 \\
\hline & NF & 4,49 & 0 & 4,49 & 1,12 \\
\hline \multirow{3}{*}{ Chemical } & I.Ex & 1,1 & 0 & 1,1 & 1,05 \\
\hline & G.Hyd & 1,58 & 0 & 1,58 & 0,63 \\
\hline & LLE & 6 & 0 & 6 & 0,4 \\
\hline \multicolumn{2}{|c|}{ Absorption (Abs) } & 1,38 & 0 & 1,38 & 0,2 \\
\hline
\end{tabular}


FO is however still being commercialized with continuing developments in membranes and draw solutions. Also the regeneration of draw solution is also not yet optimized [12].

\section{Conclusion}

Low salinity is gaining more and more interest, even extending its application into carbonate reservoirs. With its ability to increase OOIP from $5-40 \%$, its successful application will truly change the impact the gulf of guinea has on energy supply globally. With the presence of Devonian to Carboniferous sandstone beds, including Albian sandstone this is truly a prime location for the application of this method since it is best suited for sandstone formations. Effective and economical desalination is critical

\section{REFERENCES}

1. Petroconsultants, 1996. Petroleum Exploration and Production Database.

2. Geology and Total Petroleum Systems of the Gulf of Guinea Province of West Africa Geology. U.S. Geological Survey Bulletin 2207-CU.CU.

3. Kjemperud A., Agbesinyale W., Agdestein T., Gustafsson C., Yükler A. Tectono-stratigraphic History of the Keta Basin, Ghana with Emphasis on Late Erosional Episodes. 1992. P. 55-69.

4. Bernard G.G. Effect of Floodwater Salinity on Recovery of Oil from Cores Containing Clays. SPE California Regional Meeting. SPE-1725-MS.

5. Kilybay A., Ghosh B., Thomas N.Ch. A Review on the Progress of Ion-Engineered Water Flooding. Hindawi, Journal of Petroleum Engineering.

6. Alvarado V., Manrique E. Enhanced Oil Recovery: An Update Review. Energies. ISSN 1996-1073.

7. Aggrey W.N., Afari S., Kwame S. The New EOR Frontiers - Reduced Salinity Waterflooding. Asian Journal of Applied Sciences. ISSN 2321-0893.

8. El-Dessouky H., Ettouney H. Fundamentals of Sea Water Desalination. ElSEVIER. 2002.

9. Youssefa P.G., AL-Dadaha R.K., Mahmouda S.M. Comparative Analysis of Desalination Technologies. The 6th International Conference on Applied Energy, ICAE 2014.

10. Fritzmann C., Löwenberg J., Wintgens T. State-ofthe-Art of Reverse Osmosis Desalination. P. 1-40.

11. Jeffrey R. e.a. A Novel Ammonia-Carbon Dioxide Forward (Direct) Osmosis Desalination Process. P. 3-6.

12. Ayirala S.C., Yousef A.A. A Critical Review of Alternative Desalination Technologies for Smart Waterflooding. P. 4-6.

13. How Desalination by Multi-stage Flash Distillation Works [Electronic Resource]. URL: https://www.brighthubengineering.com/power-plants/29623-how-desalinationby-multi-stage-flash-distillation-works/\#imgn_0.

14. Multiple Effect Distillation (MED) [Electronic Resource]. URL: http://www.entropie.com/en/services/ desalination/MED. to itsviability an EOR method, especially in offshore conditions where technology is limited by space and weight constraints. RO is still the preferred method for desalination of seawater. However, FO seems to be superior to its counterpart RO in relation to energy consumption energy consumption, where its uses $39 \%$ less energy. It also has the ability to produce water with an even lower salinity. The technology however has yet to be commercialized [18]. Withits low cost, ability to be combined with other forms of EOR, low $\mathrm{CO}_{2}$ emissions, adaptability as a secondary and tertiary form of EOR, low salinity water flooding has a big role to play in the future development of the Gulf of Guinea and west Africa in general.

15. Lokiec F., Ophir A. The Mechanical Vapor Compression: 38 Years of Experience. IDA World CongressMaspalomas, Gran Canaria, Spain, October 21-26, 2007. REF: IDAWC/MP07-084.

16. Seccombe J.C., Lager A., Webb K.J., Jerauld G., Fueg E. Improving Wateflood Recovery: LoSalTM EOR Field Evaluation. Society of Petroleum Engineers.

17. Robbana E., Buikema T.A., Mair Ch., Williams D., Mercer D.J., Webb K.J., Hewson A., Reddick Ch.E. Low Salinity Enhanced Oil Recovery - Laboratory to Day One Field Implementation - LoSal EOR into the Clair Ridge Project. Society of Petroleum Engineers.

18. Omojola B. Investors' Paradise. Africa Today. March, 2007.

\section{СПИСОК ИСПОЛЬЗУЕМЫХ ИСТОЧНИКОВ}

1. Petroconsultants, 1996. Petroleum Exploration and Production Database.

2. Geology and Total Petroleum Systems of the Gulf of Guinea Province of West Africa Geology // U.S. Geological Survey Bulletin 2207-CU.CU.

3. Kjemperud A., Agbesinyale W., Agdestein T., Gustafsson C., Yükler A. Tectono-stratigraphic History of the Keta Basin, Ghana with Emphasis on Late Erosional Episodes. 1992. P. 55-69.

4. Bernard G.G. Effect of Floodwater Salinity on Recovery of Oil from Cores Containing Clays // SPE California Regional Meeting. SPE-1725-MS.

5. Kilybay A., Ghosh B., Thomas N.Ch. A Review on the Progress of Ion-Engineered Water Flooding // Hindawi, Journal of Petroleum Engineering.

6. Alvarado V., Manrique E. Enhanced Oil Recovery: An Update Review // Energies. ISSN 1996-1073.

7. Aggrey W.N., Afari S., Kwame S. The New EOR Frontiers - Reduced Salinity Waterflooding // Asian Journal of Applied Sciences. ISSN 2321-0893.

8. El-Dessouky H., Ettouney H. Fundamentals of Sea Water Desalination // ElSEVIER. 2002.

9. Youssefa P.G., AL-Dadaha R.K., Mahmouda S.M. Comparative Analysis of Desalination Technologies // The 
6th International Conference on Applied Energy — ICAE 2014.

10. Fritzmann C., Löwenberg J., Wintgens T. State-ofthe-Art of Reverse Osmosis Desalination. P. 1-40.

11. Jeffrey R. e.a. A Novel Ammonia-Carbon Dioxide Forward (Direct) Osmosis Desalination Process. P. 3-6.

12. Ayirala S.C., Yousef A.A. A Critical Review of Alternative Desalination Technologies for Smart Waterflooding. P. 4-6.

13. How Desalination by Multi-stage Flash Distillation Works [Electronic Resource]. URL: https://www.brighthubengineering.com/power-plants/29623-how-desalinationby-multi-stage-flash-distillation-works/\#imgn_0.

14. Multiple Effect Distillation (MED) [Electronic Resource]. URL: http://www.entropie.com/en/services/ desalination/MED.

\section{ABOUT THE AUTHOR}

\section{СВЕДЕНИЯ ОБ АВТОРЕ}

Йебоах Раиса, аспирант, Российский государственный университет нефти и газа (Нацчиональный исследовательский университет) имени И.М. Губкина, г. Москва, Российская Федерация

Raisa Yeboah, Post-graduate Student, Gubkin Russian State University of Oil and Gas (National Research University), Moscow, Russian Federation

e-mail: raisayeb@yahoo.com
15. Lokiec F., Ophir A. The Mechanical Vapor Compression: 38 Years of Experience // IDA World CongressMaspalomas, Gran Canaria, Spain, October 21-26, 2007. REF: IDAWC/MP07-084.

16. Seccombe J.C., Lager A., Webb K.J., Jerauld G., Fueg E. Improving Wateflood Recovery: LoSalTM EOR Field Evaluation // Society of Petroleum Engineers.

17. Robbana E., Buikema T.A., Mair Ch., Williams D., Mercer D.J., Webb K.J., Hewson A., Reddick Ch.E. Low Salinity Enhanced Oil Recovery - Laboratory to Day One Field Implementation - LoSal EOR into the Clair Ridge Project // Society of Petroleum Engineers.

18. Omojola B. Investors' Paradise // Africa Today. March, 2007. 